\title{
Epitaxial $\mathrm{SrRuO}_{3}$ Thin Films Deposited on SrO buffered-Si(001) Substrates for Ferroelectric $\mathrm{Pb}\left(\mathrm{Zr}_{0.2} \mathrm{Ti}_{0.8}\right) \mathrm{O}_{3}$ Thin Films
}

\author{
Soon-Gil Yoon \\ School of Nano Science and Technology, Graduate of Analytical Science and Technology \\ (GRAST), Chungnam National University, Daeduk Science Town, 305-764, Daejeon \\ Korea
}

\section{Introduction}

At present there is considerable interest in utilizing ferroelectric thin films as a medium for non-volatile data storage [1]. In particular, much attention has been focused on investigating high density giga-bit data storage using scanning probe techniques [2]. It is known that the thickness of a $180^{\circ}$ domain wall in ferroelectric thin film is 1-2 $\mathrm{nm}$ [3]. As such, these films have potential to serve as a medium for scanning probe microscopy (SPM)-based ultrahigh density (100 Gbit $/ \mathrm{cm}^{2}$ class) data storage [2]. It has been proposed that employing ferroelectric films as recording media inherently has several advantages: 1) the recorded data are non-volatile, 2) the recording density can be ultra high because of narrow domain wall thickness, 3) the ferroelectric domains can have fast switching speeds, and 4) information bits can be written and read electrically.

Among the various perovskite oxide materials, PZT films appear to be suitable as a storage medium, since their remanent polarizations are high. The highly tetragonal PZT films exhibit high remanent polarization showing a square-shaped hysteresis curve, compared with films having morphotropic and rhombohedral compositions. Therefore, $\mathrm{Pb}\left(\mathrm{Zr}_{0.2} \mathrm{Ti}_{0.8}\right) \mathrm{O}_{3}$ films with a highly tetragonal structure are suitable for nano-data storage system applications. Ferroelectric $\mathrm{Pb}\left(\mathrm{Zr}_{0.2} \mathrm{Ti}_{0.8}\right) \mathrm{O}_{3}$ thin films grown epitaxially on $\mathrm{SrRuO}_{3} / \mathrm{SrTiO}_{3}$ are reported to exhibit large $\mathrm{P}_{\mathrm{r}}$ (remanent polarization) [4-5].

$\mathrm{SrRuO}_{3}$ is a conductive oxide (a room temperature resistivity of $280 \mu \Omega \cdot \mathrm{cm}$ for single crystals), pseudo-cubic perovskite with a lattice constant of $0.55 \mathrm{~nm}$, and has a low mismatch with $\mathrm{Pb}\left(\mathrm{Zr}_{0.2} \mathrm{Ti}_{0.8}\right) \mathrm{O}_{3}(\sim 0.5 \%)$ and $\mathrm{SrO}(\sim 1.7 \%)$, thus allowing high quality epitaxial growth. Singlecrystal epitaxial thin films of $\mathrm{SrRuO}_{3}$ and $\mathrm{Sr}_{1-x} \mathrm{Ca}_{x} \mathrm{RuO}_{3}[6]$ are frequently grown on $\mathrm{SrTiO}_{3}$ substrates. In order to achieve epitaxial growth of $\mathrm{SrRuO}_{3}$ on $\mathrm{Si}$, yttria-stabilized zirconia (YSZ) [7-8] and $\mathrm{MgO}$ [9] have been employed as buffer layer materials. Another promising candidate for the buffer layer is $\mathrm{SrO}$ which has a $\mathrm{NaCl}$-type cubic structure with a lattice parameter of $\mathrm{a}=$ $5.140 \AA$ [10-11]. The $\mathrm{SrO}(110)$ dielectric layer also exhibits good compatibility with $\mathrm{Si}(001)$ showing a low lattice mismatch of about $0.4 \%$ [12].

In this study, highly tetragonal $\mathrm{Pb}\left(\mathrm{Zr}_{0.2} \mathrm{Ti}_{0.8}\right) \mathrm{O}_{3}$ films were grown on epitaxial $\mathrm{SrRuO}_{3}$ thin film electrodes using a $\mathrm{SrO}$ buffer layer on $\mathrm{Si}(001)$ substrates by pulsed laser deposition. The effect of the SrO buffer layer on the surface morphologies and the electrical properties of the 
$\mathrm{SrRuO}_{3}$ thin film electrodes was investigated as a function of $\mathrm{SrO}$ buffer layer thickness. Ferroelectric properties in c-axis oriented $\mathrm{Pb}\left(\mathrm{Zr}_{0.2} \mathrm{Ti}_{0.8}\right) \mathrm{O}_{3}$ thin films deposited on an epitaxial $\mathrm{SrRuO}_{3}$ electrode were also investigated.

\section{Experimental procedure}

The $\mathrm{SrO}$ target for pulsed laser deposition is difficult to make due to the low sinterability of $\mathrm{SrO}$ materials. $\mathrm{A} \mathrm{SrO}_{2}$ target was used to deposit $\mathrm{SrO}$ on $\mathrm{Si}$ (001) substrates in a vacuum ambient. Before deposition of SrO layers on Si (001) substrates, Si wafers were etched using $\mathrm{HF}$ solution to remove the native oxide layers. $\mathrm{SrO}, \mathrm{SrRuO}_{3}$ and $\mathrm{PZT}$ films were deposited on etched-silicon substrates using a $\mathrm{KrF}$ excimer laser $(\lambda=248 \mathrm{~nm})$ with a maximum repetition rate of $10 \mathrm{~Hz}$. Laser pulse energy density used for $\mathrm{SrO}, \mathrm{SrRuO}_{3}$ and $\mathrm{PZT}$ films deposited using ceramic targets was approximately $1.5 \mathrm{~J} / \mathrm{cm}^{2} .30 \mathrm{~mol} \%$ excess $\mathrm{PbO}$ in the PZT targets was added to compensate for the $\mathrm{PbO}$ loss during both the sintering and deposition processes. The distance between the target and substrate was varied depending on the deposited materials. The typical $\mathrm{SrO}, \mathrm{SrRuO}_{3}$, and PZT deposition conditions are summarized in Table 1. The SrO, $\mathrm{SrRuO}_{3}$, and PZT were in-situ deposited at each temperature in order to ensure chemical stability of the SrO films with Si. The PZT films were cooled down to room temperature at an oxygen pressure of 300 Torr to preserve the oxygen content in the films during the cooling procedure.

\begin{tabular}{|l|c|c|c|}
\hline \multicolumn{1}{|c|}{ Deposition parameters } & $\mathrm{SrO}$ & $\mathrm{SrRuO}_{3}$ & $\mathrm{~Pb}\left(\mathrm{Zr}_{0.2} \mathrm{Ti}_{0.8}\right) \mathrm{O}_{3}$ \\
\hline Target & $\mathrm{SrO}_{2}$ & $\mathrm{SrRuO}_{3}$ & $\mathrm{~Pb}\left(\mathrm{Zr}_{0.2} \mathrm{Ti}_{0.8}\right) \mathrm{O}_{3}$ \\
\hline Deposition temperature & $700^{\circ} \mathrm{C}$ & $550 \sim 750^{\circ} \mathrm{C}$ & $575 \sim 600^{\circ} \mathrm{C}$ \\
\hline Film thickness & $3 \sim 30 \mathrm{~nm}$ & $50 \sim 300 \mathrm{~nm}$ & $100 \mathrm{~nm}$ \\
\hline Deposition pressure & $1 \times 10^{-6} \mathrm{Torr}$ & $1 \times 10^{-2} \mathrm{Torr}$ & $1 \times 10^{-1} \mathrm{Torr}$ \\
\hline Energy density & $1.5 \mathrm{~J} / \mathrm{cm}^{2}$ & $1.5 \mathrm{~J} / \mathrm{cm}^{2}$ & $1.5 \mathrm{~J} / \mathrm{cm}^{2}$ \\
\hline Repetition rate & $1 \mathrm{~Hz}$ & $10 \mathrm{~Hz}$ & $10 \mathrm{~Hz}$ \\
\hline Target-substrate distance & $3 \mathrm{~cm}$ & $4 \mathrm{~cm}$ & $6 \mathrm{~cm}$ \\
\hline Substrates & $\mathrm{Si}(001)$ & $\mathrm{SrO} / \mathrm{Si}$ & $\mathrm{SrRuO}_{3} / \mathrm{SrO} / \mathrm{Si}$ \\
\hline
\end{tabular}

Table 1. Deposition conditions of $\mathrm{Pb}\left(\mathrm{Zr}_{0.2} \mathrm{Ti}_{0.8}\right) \mathrm{O}_{3}$ thin films, $\mathrm{SrRuO}_{3}$ electrodes, and $\mathrm{SrO}$ buffer layers on $\mathrm{Si}(001)$ substrates by pulsed laser deposition

The surface morphologies of $\mathrm{SrRuO}_{3}$ and PZT were characterized by atomic force microscopy (AFM, AUTOPROBE CP, PSI). Crystalline properties of the films were investigated by $\theta-2 \theta, \omega$-scan, and $\Phi$-scan using a high resolution X-ray diffraction (HRXRD, Rigaku RINT2000). The composition of the $\mathrm{SrRuO}_{3}$ films was identified by Rutherford backscattering spectroscopy (RBS) using a beam energy of $2.236 \mathrm{MeV}\left(4 \mathrm{He}^{++}\right)$and an incident angle of $160^{\circ}$. The elemental distribution in the $\mathrm{PZT} / \mathrm{SrRuO}_{3} / \mathrm{SrO} / \mathrm{Si}$ structure was investigated by secondary ion mass spectroscopy (SIMS) and Auger electron spectroscopy (AES). The resistivity of $\mathrm{SrRuO}_{3}$ thin films was measured by an electrometer (CMT-SR 1000) using a four-point probe. The ferroelectric properties and leakage current characteristics were measured using a RT66A ferroelectric tester (Radiant Technology) operating in the virtual ground mode and a Keithley 617 electrometer, respectively. The measurements were carried out using a metal-insulator-metal (MIM) configuration. A Pt top electrode (Area = $7.85 \times 10^{-5} \mathrm{~cm}^{2}$ ) patterned using lift-off lithography was prepared at room temperature by $\mathrm{dc}$ sputtering. 


\section{Results and discussion}

Figure 1(A) shows XRD patterns of $100 \mathrm{~nm}$ thick-SrRuO 3 thin films deposited on $\mathrm{SrO}$ buffer layers with various thicknesses. The XRD patterns were plotted using a log-scale to check the existence of the minor portion of $\mathrm{SrO}_{2}$ phase within the $\mathrm{SrRuO}_{3}$ films. The $\mathrm{SrRuO}_{3}$ films were deposited at about $650^{\circ} \mathrm{C}$ in $1 \times 10^{-2}$ Torr. As shown in Fig. 1(A), $\mathrm{SrRuO}_{3}$ films deposited on 6 nm-thick-SrO buffered $\mathrm{Si}(001)$ substrates exhibit a c-axis preferred orientation, indicating the (001) and (002) planes alone. In the case of buffer layers above $12 \mathrm{~nm}$ thickness, $\mathrm{SrO}_{2}$ phase was observed in the $\mathrm{SrRuO}_{3}$ films. From the XRD results, the $\mathrm{SrO}$ buffer layer was found to play an important role for the preferred growth of $\mathrm{SrRuO}_{3}$ films on $\mathrm{Si}$ substrates at below approximately $6 \mathrm{~nm}$-thickness. In order to investigate the epitaxial relationship between $\mathrm{SrRuO}_{3}$ and $\mathrm{SrO}(6 \mathrm{~nm}) / \mathrm{Si}(001)$, a $\Phi$-scan in the $\mathrm{SrRuO}_{3} / \mathrm{SrO} / \mathrm{Si}$ structure was performed and the results are shown in Fig. 1 (B). Peaks of $\mathrm{SrRuO}_{3}\{111\}$ can be observed at every 90。, indicating that the $\mathrm{SrRuO}_{3}$ films are epitaxially grown on a $\mathrm{SrO} / \mathrm{Si}(001)$.
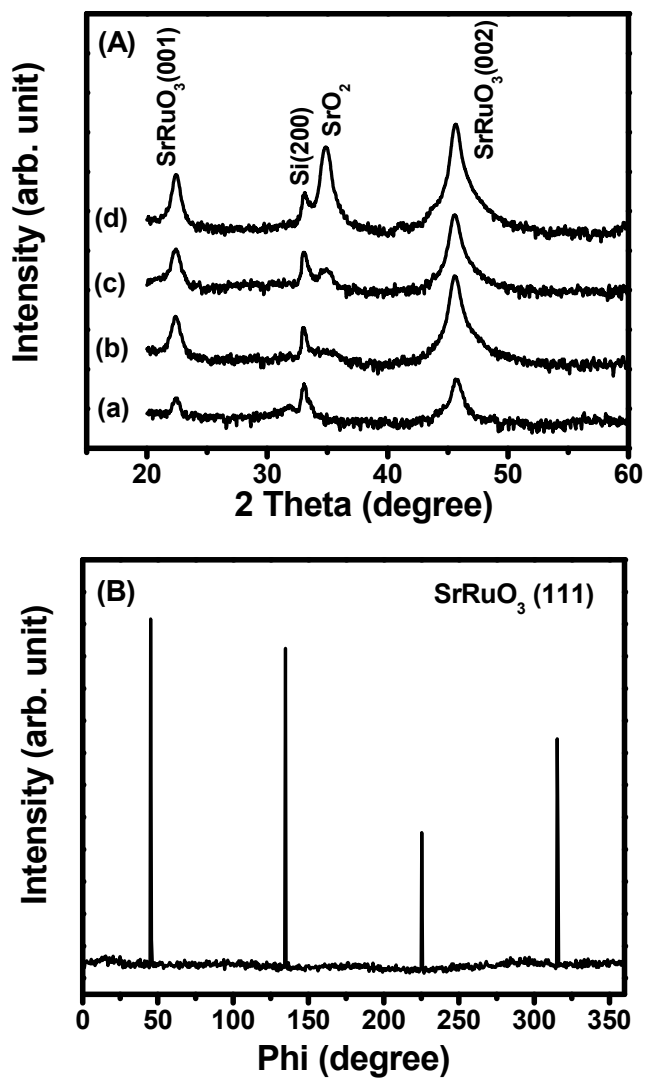

Fig. 1. (A) XRD patterns of $100 \mathrm{~nm}$ thick-SrRuO 3 thin films deposited on $\mathrm{SrO}$ buffer layers of (a) $3 \mathrm{~nm}$, (b) $6 \mathrm{~nm}$, (c) $12 \mathrm{~nm}$, and (d) $30 \mathrm{~nm}$ thickness. (B) $\Phi$-scan profile of $\mathrm{SrRuO}_{3}$ films deposited on $\mathrm{SrO}(6 \mathrm{~nm}) / \mathrm{Si}$. (XRD patterns were plotted using a log-scale) 
Figure 2 shows the variation in resistivity and rms roughness of $100 \mathrm{~nm}$ thick-SrRuO 3 thin films as a function of $\mathrm{SrO}$ thickness. The $\mathrm{SrRuO}_{3}$ films deposited on ultra-thin $\mathrm{SrO}$ films of about $3 \mathrm{~nm}$ show the highest rms roughness and resistivity values because the $\mathrm{SrO}$ films do not play a role as a buffer layer. On the other hand, above $6 \mathrm{~nm}$ thickness, $\mathrm{SrRuO}_{3}$ films exhibit a low rms roughness of about 3-5 $\AA$ and a resistivity of $1700-1900 \mu \Omega-\mathrm{cm}$. The resistivity values of the $\mathrm{SrRuO}_{3}$ films deposited on $6 \mathrm{~nm}$-thick SrO buffer layers are approximately $1700 \mu \Omega$-cm, higher than that of $\mathrm{SrRuO}_{3}$ films $(\sim 400 \mu \Omega-\mathrm{cm})$ deposited on $\mathrm{SrTiO}_{3}$ single crystals[13] and (100) $\mathrm{LaAlO}_{3}$ single crystals[14]. The high resistivity of the $\mathrm{SrRuO}_{3}$ films on Si substrates originates from the existence of silicon oxide formed from the diffusion of silicon, because the thin $\mathrm{SrO}$ layer does not prevent the diffusion of silicon during the deposition of $\mathrm{SrRuO}_{3}$ at high temperature. The full-width-half-maximum (FWHM) values of the $\mathrm{SrRuO}_{3}$ films deposited on $\mathrm{SrO} / \mathrm{Si}$ and $\mathrm{SrTiO}_{3}$ single crystal substrates are approximately $7.32^{\circ}$ and $0.15^{\circ}$, measured by $\omega-$ scan, respectively. These results suggest that the $\mathrm{SrRuO}_{3}$ films grown on $\mathrm{Si}$ substrates are inferior in terms of film qualities such as crystallinity and defects relative to those grown on $\mathrm{SrTiO}_{3}$ single crystals. The inset in Fig. 2 shows three-dimensional AFM images of $\mathrm{SrRuO}_{3}$ films deposited on (a) $3 \mathrm{~nm}$ thick- and (b) $30 \mathrm{~nm}$ thick-SrO buffer layers.

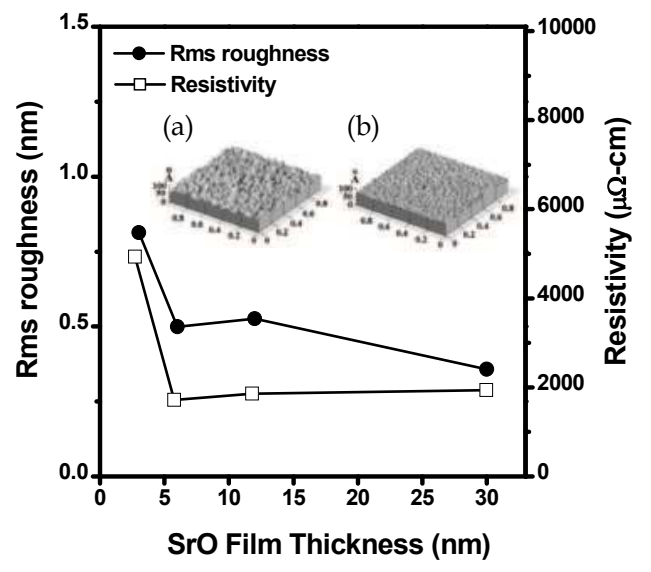

Fig. 2. Variation in resistivity and rms roughness of $100 \mathrm{~nm}$ thick-SrRuO 3 thin films as a function of $\mathrm{SrO}$ thickness. The inset shows three-dimensional AFM images of $\mathrm{SrRuO}_{3}$ thin films deposited on $\mathrm{SrO}$ buffer layers of (a) $3 \mathrm{~nm}$ and (b) $30 \mathrm{~nm}$ thickness

Figures 3(a) and 3(b) show XRD patterns and rms roughness and resistivity of $\mathrm{SrRuO}_{3}$ films, respectively, as a function of $\mathrm{SrRuO}_{3}$ thickness. The $\mathrm{SrRuO}_{3}$ films were deposited at $650^{\circ} \mathrm{C}$ on $6 \mathrm{~nm}$ thick-SrO buffer layers. As shown in Fig. 3(a), the peak intensity of $\mathrm{SrRuO}_{3}\{001\}$ increases with increasing $\mathrm{SrRuO}_{3}$ thickness, and the $\mathrm{SrRuO}_{3}$ films of $50 \mathrm{~nm}$ thickness also exhibit a $c$-axis preferred relationship with $\mathrm{Si}(001)$ substrates. The resistivity of the $\mathrm{SrRuO}_{3}$ films exhibits a constant value of about $1700 \mu \Omega$-cm irrespective of the film thickness above $50 \mathrm{~nm}$. The rms roughness of the $\mathrm{SrRuO}_{3}$ films exhibits a similar tendency with the variation of resistivity as a function of $\mathrm{SrRuO}_{3}$ thickness. The film roughness in conducting materials is inversely proportional to the mobility of the charge carriers. The resistivity in the conducting films is also inversely proportional to the mobility of the charge carriers if the concentration of the charge carriers is constant. 

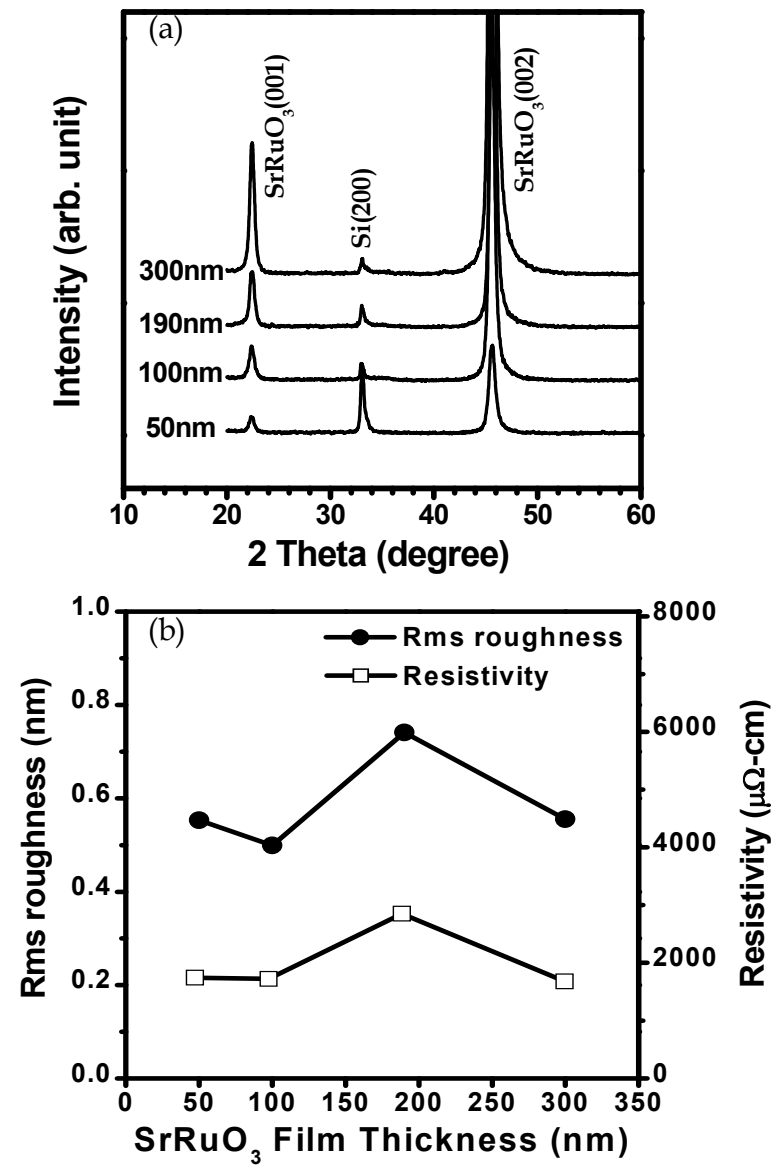

Fig. 3. (a) XRD patterns, (b) rms roughness and resistivity of the $\mathrm{SrRuO}_{3}$ films deposited on $6 \mathrm{~nm}$-thick $\mathrm{SrO}$ buffer layers as a function of $\mathrm{SrRuO}_{3}$ thickness

Figure 4(a) and 4(b) show XRD patterns and variation of rms roughness and resistivity, respectively, for 190nm-thick $\mathrm{SrRuO}_{3}$ films as a function of $\mathrm{SrRuO}_{3}$ deposition temperature. As shown in Fig. 4(a), $\mathrm{SrRuO}_{3}$ films deposited at 550 and $600^{\circ} \mathrm{C}$ show $\mathrm{SrRuO}_{3}$ (110) peaks in addition to the $\mathrm{SrRuO}_{3}\{001\}$ peaks. This indicates that the films deposited at lower temperatures exhibit a polycrystalline nature rather than an epitaxial relationship. The $\mathrm{SrRuO}_{3}(110)$ peak disappears in the films deposited above $650^{\circ} \mathrm{C}$ and the films are grown with an epitaxial relationship with Si (001) substrates. As shown in Fig. 4(b), the rms roughness of the films continuously increases with increasing deposition temperature, and a rms roughness of $7.4 \AA$ is noted in the films deposited at $650^{\circ} \mathrm{C}$. The rms roughness of the $\mathrm{SrRuO}_{3}$ films deposited on $\mathrm{SrO} / \mathrm{Si}$ substrates is higher than that of the films deposited on $\mathrm{SrTiO}_{3}$ single crystals [13]. In the $\mathrm{SrRuO}_{3} / \mathrm{SrO} / \mathrm{Si}$ structure, even though the films deposited above $650^{\circ} \mathrm{C}$ were epitaxially grown, the high rms roughness of the $\mathrm{SrRuO}_{3}$ films was 
attributed to the unstable interface structure of $\mathrm{SrO} / \mathrm{Si}$, compared with the $\mathrm{SrTiO}_{3}$ single crystal substrate. The resistivity of the $\mathrm{SrRuO}_{3}$ films abruptly decreases as the deposition temperature increases up to $650^{\circ} \mathrm{C}$ and maintains a constant value of about $1700 \mu \Omega$-cm at deposition temperatures above $6500^{\circ} \mathrm{C}$. The $\mathrm{SrRuO}_{3}$ films grown with an epitaxial relationship exhibit lower resistivity than the polycrystalline films.
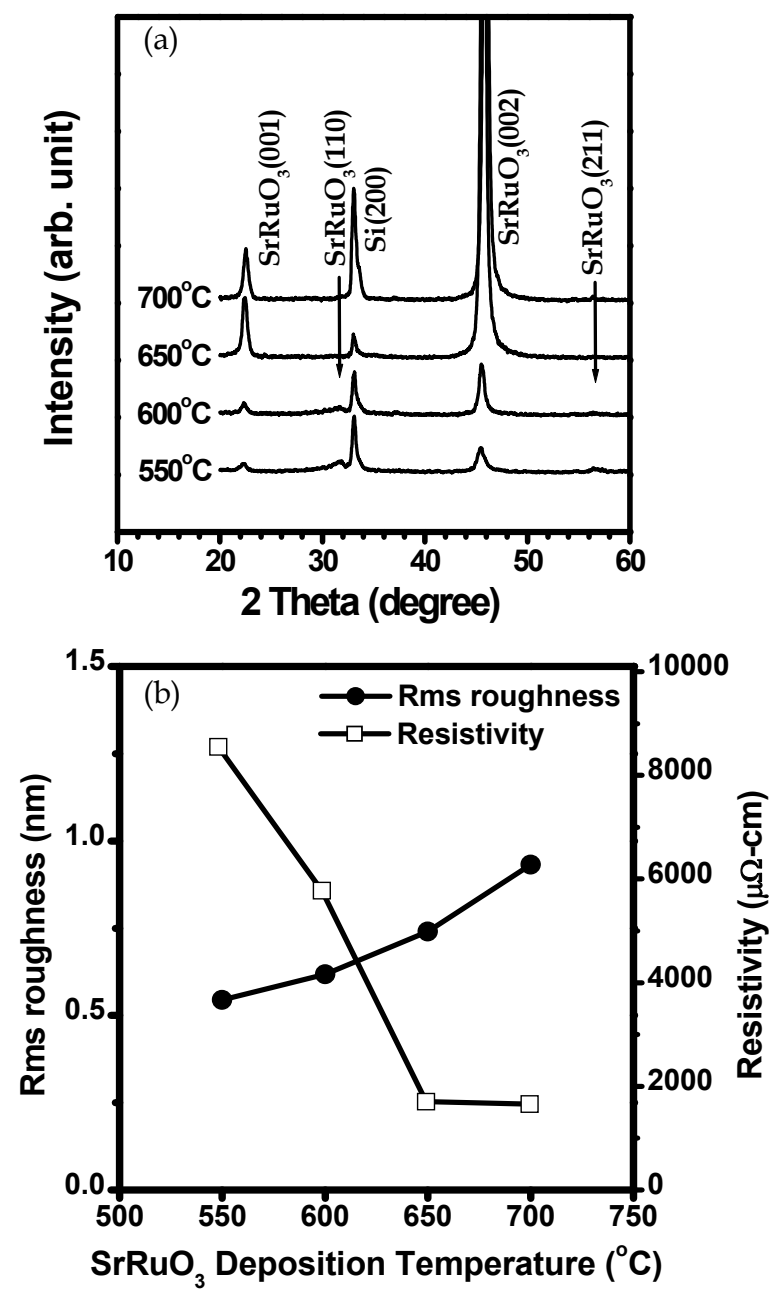

Fig. 4. (a) XRD patterns and (b) rms roughness and resistivity of the $\mathrm{SrRuO}_{3}$ films deposited on $6 \mathrm{~nm}$-thick $\mathrm{SrO}$ buffer layers as a function of $\mathrm{SrRuO}_{3}$ deposition temperature

Figure 5 shows the RBS spectrum of $190 \mathrm{~nm}$ thick-SrRuO 3 films deposited at $650^{\circ} \mathrm{C}$ on $\mathrm{SrO} / \mathrm{Si}$ substrates. The compositions of $\mathrm{Sr}$ and $\mathrm{Ru}$ in the $\mathrm{SrRuO}_{3}$ films deposited from stoichiometric $\mathrm{SrRuO}_{3}$ targets are $\mathrm{Sr} /(\mathrm{Sr}+\mathrm{Ru})=50.52 \%$ and $\mathrm{Ru} /(\mathrm{Sr}+\mathrm{Ru})=49.48 \%$ from the RBS analysis. Because the Sr and Ru elements are overlapped, the composition of the films 
was fitted by repeated adjustments with the standard composition of $\mathrm{SrRuO}_{3}$. The results suggest that the epitaxial $\mathrm{SrRuO}_{3}$ films deposited by pulsed laser deposition show the same composition as $\mathrm{SrRuO}_{3}$ targets.

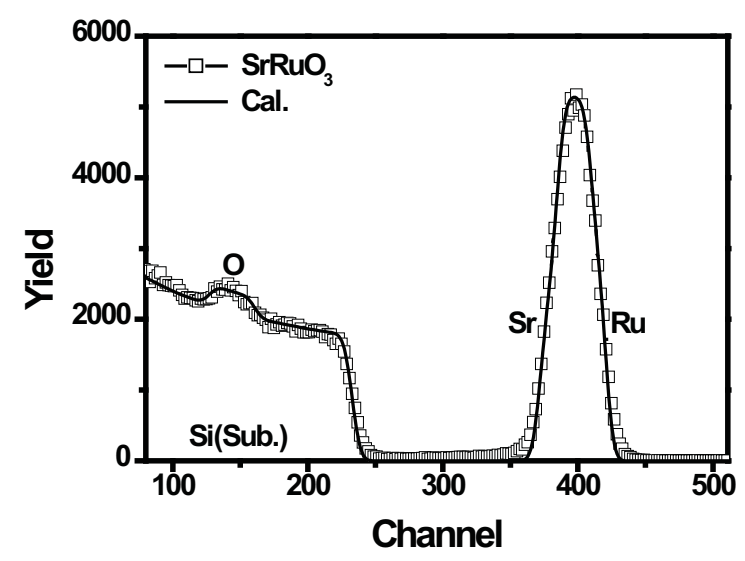

Fig. 5. RBS spectrum of $190 \mathrm{~nm}$-thick $\mathrm{SrRuO}_{3}$ films deposited at $650 \circ \mathrm{C}$ on $\mathrm{SrO} / \mathrm{Si}$ substrates

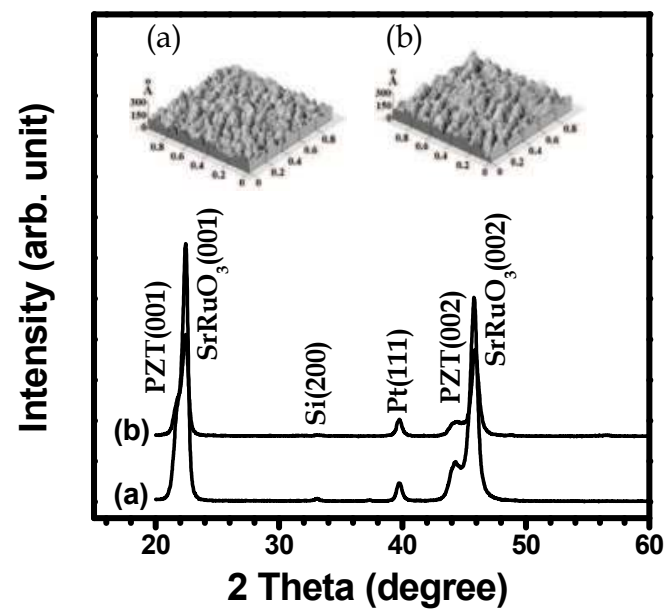

Fig. 6. XRD patterns of PZT thin films deposited at (a) $575^{\circ} \mathrm{C}$ and (b) $600^{\circ} \mathrm{C}$ on $190 \mathrm{~nm}$-thick $\mathrm{SrRuO}_{3}$ films. The insets show three-dimensional AFM images of PZT films deposited at (a) $575^{\circ} \mathrm{C}$ and (b) $600^{\circ} \mathrm{C}$

Figure 6 shows XRD patterns of $100 \mathrm{~nm}$ thick- $\mathrm{Pb}\left(\mathrm{Zr}_{0.2} \mathrm{Ti}_{0.8}\right) \mathrm{O}_{3}$ (PZT) films deposited at 575 and $600{ }^{\circ} \mathrm{C}$ on epitaxial $\mathrm{SrRuO}_{3} / \mathrm{SrO} / \mathrm{Si}$ substrates. The (a) and (b) in inset of Fig. 6 show three dimensional AFM images of PZT films deposited at $575^{\circ} \mathrm{C}$ and $600^{\circ} \mathrm{C}$, respectively. The rms roughness of the PZT films deposited at 575 and $600^{\circ} \mathrm{C}$ are approximately $23 \AA$ and $26 \AA$, respectively. The PZT films, as revealed in the XRD patterns of Fig. 6, exhibit a close 
relationship with $\mathrm{SrRuO}_{3}\{001\}$ at deposition temperatures of 575 and $600{ }^{\circ} \mathrm{C}$. The Pt (111) peak originates from the top electrode in the $\mathrm{Pt} / \mathrm{PZT} / \mathrm{SrRuO}_{3} / \mathrm{SrO} / \mathrm{Si}$ capacitor structures. However, the peak intensities of PZT $\{001\}$ decrease with increasing deposition temperature. The PZT films react with the $\mathrm{SrRuO}_{3}$ bottom electrode at high deposition temperature, resulting in $\mathrm{Pb}$ diffusion into the $\mathrm{SrRuO}_{3} / \mathrm{SrTiO}_{3}$ [15]. Even though $\mathrm{Pb}$ is diffused into the $\mathrm{SrRuO}_{3}$ films, PZT films deposited on $\mathrm{SrRuO}_{3} / \mathrm{SrTiO}_{3}$ exhibit a good epitaxial relationship maintaining the predominating crystallinity. In order to investigate the distributions of each element in the PZT films deposited on $\mathrm{SrRuO}_{3} / \mathrm{SrO} / \mathrm{Si}$, the elemental distribution in each layer was analyzed by secondary ion mass spectroscopy (SIMS), as shown in Fig. 7 (a). The $\mathrm{Pb}$ from the PZT films deposited at $600^{\circ} \mathrm{C}$ was clearly observed within the $\mathrm{SrRuO}_{3}$ layer, indicating similar diffusion behavior of $\mathrm{Pb}$ into the $\mathrm{SrRuO}_{3} / \mathrm{SrTiO}_{3}$ [15]. In addition, silicon was also observed at the PZT layer as well as at the $\mathrm{SrRuO}_{3}$ layer. The silicon existing in the PZT and $\mathrm{SrRuO}_{3}$ films will present as silicon oxide, because silicon oxide phase is thermodynamically stable compared with Si element. The silicon oxide will exert a harmful influence upon the crystallinity and the morphologies of the PZT films. The existence of silicon in the PZT layer and $\mathrm{Pb}$ in the $\mathrm{SrRuO}_{3}$ layer was also verified by the AES depthprofile as shown in Fig. 7(b). A phi-scan was performed to identify whether the PZT films are epitaxially grown on the $\mathrm{SrRuO}_{3}$ films. From the results (not shown here), PZT films do not exhibit epitaxial growth on the $\mathrm{SrRuO}_{3}$ bottom electrode. The PZT films were only grown with (001) preferred orientation on $\mathrm{SrRuO}_{3}$ electrodes. From the $\omega$-scan of the PZT films deposited at $575^{\circ} \mathrm{C}$, the FWHM value of the PZT (002) is approximately $7.08^{\circ}$. Thus, the crystalline quality of the PZT films deposited on $\mathrm{SrRuO}_{3} / \mathrm{SrO} / \mathrm{Si}$ was distinctly influenced by the silicon oxide within the PZT layers.
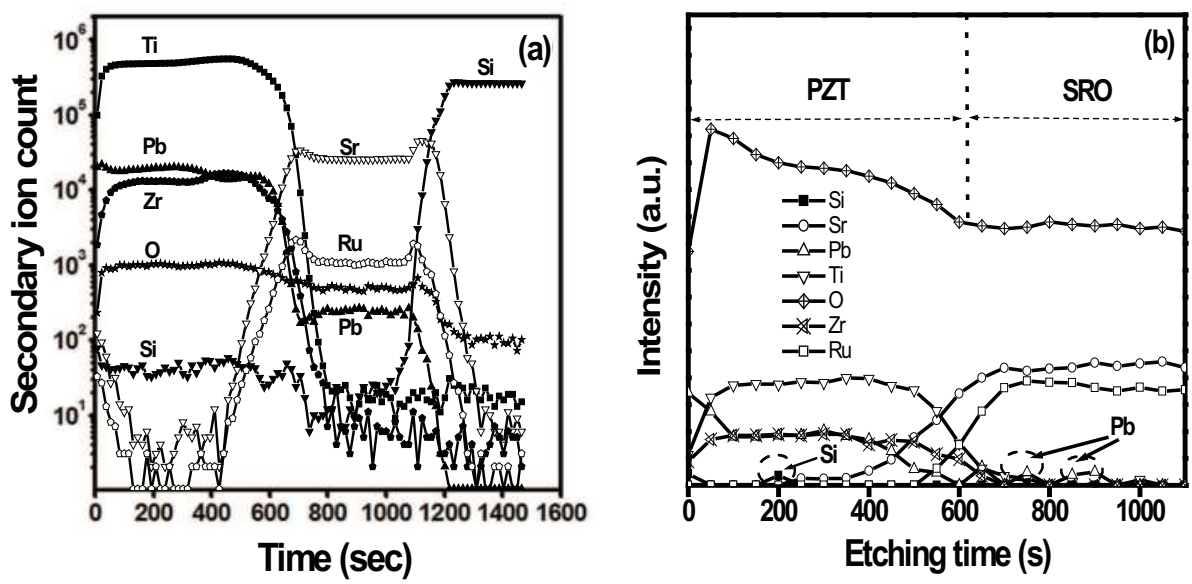

Fig. 7. (a) SIMS and (b) AES depth-profiles of PZT (100nm) films deposited at $600^{\circ} \mathrm{C}$ on $\mathrm{SrRuO}_{3} / \mathrm{SrO} / \mathrm{Si}$

Figures 8(a) and 8(b) show P-E hysteresis loops and leakage current densities, respectively, as a function of applied voltage in $100 \mathrm{~nm}$ thick-PZT films deposited at 575 and $600{ }^{\circ} \mathrm{C}$. The PZT films deposited at both temperatures show similar P-E hysteresis loops, and were polycrystalline nature. The $2 \mathrm{P}_{\mathrm{r}}$ (remanent polarization) and $\mathrm{E}_{\mathrm{c}}$ (coercive field) of the PZT films are approximately $40 \mu \mathrm{C} / \mathrm{cm}^{2}$ and $100 \mathrm{kV} / \mathrm{cm}$, respectively. The lower $P_{\mathrm{r}}$ values 
relative to reported values may be due to the poor crystallization of the PZT films resulting from inclusion of silicon oxide phase. As shown in Fig. 8(b), leakage current densities of the PZT films deposited at $575^{\circ} \mathrm{C}$ are approximately $2 \times 10^{-7} \mathrm{~A} / \mathrm{cm}^{2}$ at $1 \mathrm{~V}$. The breakdown strength of the films was approximately $150 \mathrm{kV} / \mathrm{cm}$. The lower breakdown strength of the films may be due to the rough surface morphologies, as shown in the inset of Fig. 6.
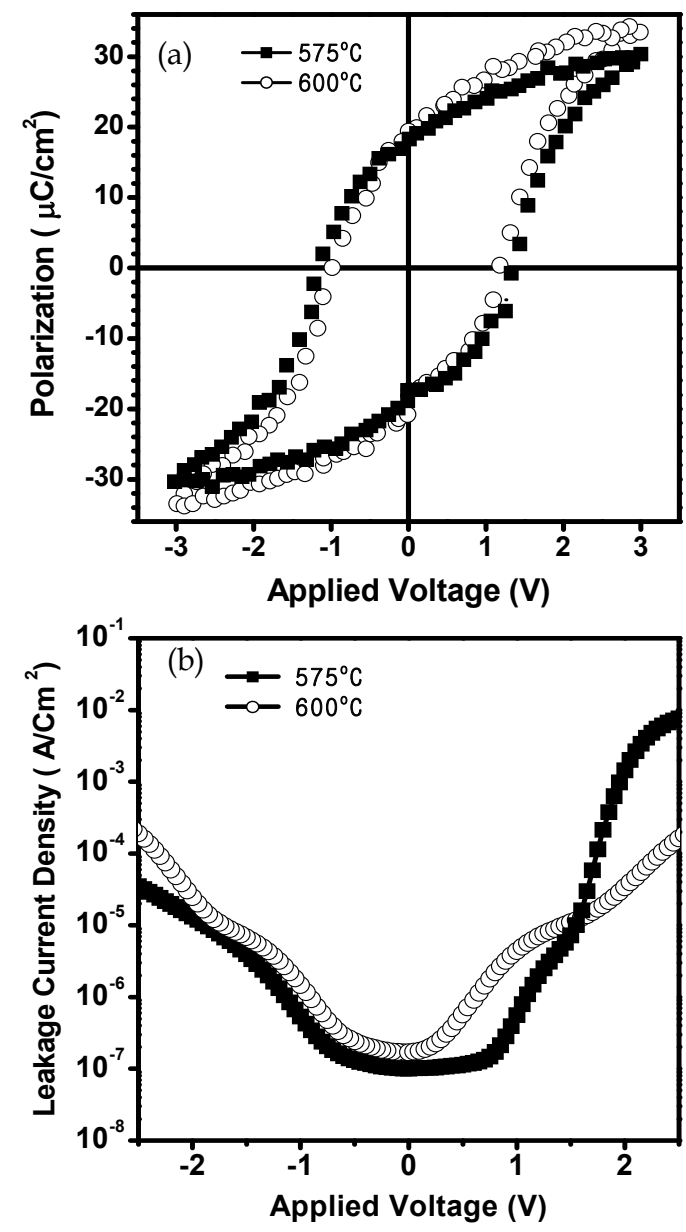

Fig. 8. (a) P-E hysteresis loops and (b) leakage current densities of 100nm thick-PZT thin films deposited at $575^{\circ} \mathrm{C}$ and $600^{\circ} \mathrm{C}$

\section{Conclusions}

$\mathrm{SrRuO}_{3}$ bottom electrodes were grown with an epitaxial relationship with $\mathrm{SrO}$ buffered$\mathrm{Si}(001)$ substrates by pulsed laser deposition. The structural and electrical properties of the $\mathrm{SrRuO}_{3}$ films were studied with deposition parameters of $\mathrm{SrRuO}_{3}$ on the optimized $\mathrm{SrO}$ 
buffer layered $\mathrm{Si}(001)$ substrates. The optimum conditions of $\mathrm{SrO}$ buffer layers for $\mathrm{SrRuO}_{3}$ preferred growth were a deposition temperature of $700^{\circ} \mathrm{C}$, deposition pressure of $1 \times 10^{-6}$ Torr, and thickness of $6 \mathrm{~nm}$. 100nm thick-SrRuO ${ }_{3}$ bottom electrodes deposited at $650{ }^{\circ} \mathrm{C}$ on $\mathrm{SrO}$ buffered-Si(001) substrates showed a rms roughness of approximately $5.0 \AA$ and a resistivity of $1700 \mu \Omega$-cm. $100 \mathrm{~nm}$ thick- $\mathrm{Pb}\left(\mathrm{Zr}_{0.2} \mathrm{Ti}_{0.8}\right) \mathrm{O}_{3}$ thin films deposited at $575 \circ \mathrm{C}$ on $\mathrm{SrRuO}_{3} / \mathrm{SrO} / \mathrm{Si}$ substrates showed a $(00 l)$ preferred orientation and exhibited a $2 \mathrm{P}_{\mathrm{r}}$ of 40 $\mu \mathrm{C} / \mathrm{cm}^{2}$ and a $E_{c}$ of $100 \mathrm{kV} / \mathrm{cm}$. The leakage current density of the PZT films was approximately $1 \times 10^{-7} \mathrm{~A} / \mathrm{cm}^{2}$ at $1 \mathrm{~V}$. The silicon oxide phase, which presents within the PZT and $\mathrm{SrRuO}_{3}$ films, influences the crystallinity of the PZT films and the resistivity of the $\mathrm{SrRuO}_{3}$ electrodes.

\section{Acknowledgments}

This research was funded by the Center for Ultramicrochemical Process Systems sponsored by KOSEF, through a Korea Science and Engineering Foundation(KOSEF) grant funded by the Korean government (MOST) (R01-2007-000-21017-0), and was also supported by the BK 21 project.

\section{References}

[1] J.F. Scott, Ferroelectric memories, Vol. 3 of the Springer series on Advanced Microelectronics, Springer, Heidelberg, April 2000.

[2] T. Hidaka, T. Mayurama, M. Saitoh, N. Mikoshiba, M. Shimizu, T. Shiosaki, L.A. Wills, R. Hiskes, S.A. Dicarolis, and J. Amano, Appl. Phys. Lett. 68, 1996, 2358.

[3] M.E. Lines and A.M. Glass, Principles and Applications of Ferroelectrics and Related Materials, Oxford University Press, Oxford, England, 1977, p. 525.

[4] W.S. Lee, K.C. Ahn, C.S. Kim, and S.G. Yoon, J. Vac. Sci. Technol. B 23 (2005) 1901.

[5] W.S. Lee, K.C. Ahn, H.J. Shin, Y.S. Kim, K.S. No, and S.G. Yoon, Integr. Ferroelectr. 73 (2005) 125.

[6] C.B. Eom, R.J. Cava, R.M. Fleming, J.M. Phillips, R.B. VanDover, J.H. Marshall, J.W.P. Hsu, J.J. Krajewski, and W.F. Peck Jr., Science, 258 (1992) 1766.

[7] P. Legagneux, G. Garry, D. Dieumegard, C. Schwebel, C. Pellet, G. Gautherin, and J. Siejka, Appl. Phys. Lett. 53 (1988) 1506.

[8] D.K. Fork, D.B. Fenner, G.A.N. Connell, J.M. Phillips, and T.H. Geballe, Appl. Phys. Lett. 57 (1990) 1137.

[9] D.K. Fork, F.A. Ponce, J.C. Tramontana, and T.H. Geballe, Appl. Phys. Lett. 58 (1991) 2294.

[10] Y. Kado and Y. Arita, J. Appl. Phys. 61 (1987) 2398.

[11] S.K. Singh and S.B. Palmer, Ferroelectrics, 328 (2005) 85

[12] T. Higuchi, Y. Chen, J. Koike, S. Iwashita, M. Ishida, and T. Shimoda, Jpn. J. Appl. Phys. 41 (2002) 6867.

[13] W.S. Lee, K.C. Ahn, and S.G. Yoon, J. Vac. Sci. Technol. B 23 (2005) 1901.

[14] Q.X. Jia, F. Chu, C.D. Adams, X.D. Wu, M. Hawley, J.H. Cho, A.T. Findikoglu, S.R. Foltyn, J.L. Smith, and T.E. Mitchell, J. Mater. Res. 11 (1996) 2263.

[15] W.S. Lee, G.H. Jung, D.H. Kim, S.W. Kim, H.J. Kim, J.R. Park, Y.P. Song, H.K. Yoon, S.M. Lee, I.H. Choi, and S.G. Yoon, J. of KIEEME, 18 (2005) 810. 


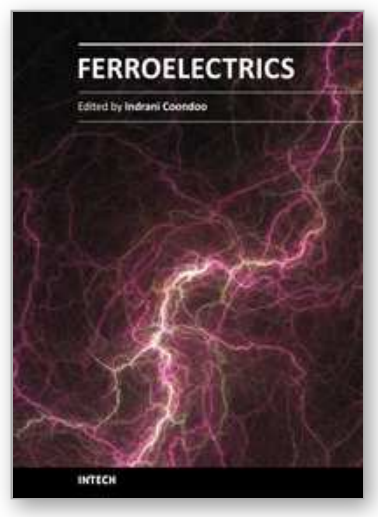

\author{
Ferroelectrics \\ Edited by Dr Indrani Coondoo
}

ISBN 978-953-307-439-9

Hard cover, 450 pages

Publisher InTech

Published online 14, December, 2010

Published in print edition December, 2010

Ferroelectric materials exhibit a wide spectrum of functional properties, including switchable polarization, piezoelectricity, high non-linear optical activity, pyroelectricity, and non-linear dielectric behaviour. These properties are crucial for application in electronic devices such as sensors, microactuators, infrared detectors, microwave phase filters and, non-volatile memories. This unique combination of properties of ferroelectric materials has attracted researchers and engineers for a long time. This book reviews a wide range of diverse topics related to the phenomenon of ferroelectricity (in the bulk as well as thin film form) and provides a forum for scientists, engineers, and students working in this field. The present book containing 24 chapters is a result of contributions of experts from international scientific community working in different aspects of ferroelectricity related to experimental and theoretical work aimed at the understanding of ferroelectricity and their utilization in devices. It provides an up-to-date insightful coverage to the recent advances in the synthesis, characterization, functional properties and potential device applications in specialized areas.

\title{
How to reference
}

In order to correctly reference this scholarly work, feel free to copy and paste the following:

Soon-Gil Yoon (2010). Epitaxial SrRuO3 Thin Films Deposited on SrO buffered-Si(001) Substrates for Ferroelectric $\mathrm{Pb}(\mathrm{Zr0}$.2Ti0.8)O3 Thin Films, Ferroelectrics, Dr Indrani Coondoo (Ed.), ISBN: 978-953-307-4399, InTech, Available from: http://www.intechopen.com/books/ferroelectrics/the-structural-and-ferroelectricproperties-of-the-epitaxial-thin-films-grown-on-appropriate-buffer-

\section{INTECH}

open science | open minds

\section{InTech Europe}

University Campus STeP Ri

Slavka Krautzeka 83/A

51000 Rijeka, Croatia

Phone: +385 (51) 770447

Fax: +385 (51) 686166

www.intechopen.com

\section{InTech China}

Unit 405, Office Block, Hotel Equatorial Shanghai

No.65, Yan An Road (West), Shanghai, 200040, China

中国上海市延安西路65号上海国际贵都大饭店办公楼 405 单元

Phone: +86-21-62489820

Fax: +86-21-62489821 
(C) 2010 The Author(s). Licensee IntechOpen. This chapter is distributed under the terms of the Creative Commons Attribution-NonCommercialShareAlike-3.0 License, which permits use, distribution and reproduction for non-commercial purposes, provided the original is properly cited and derivative works building on this content are distributed under the same license. 